\title{
SETAHUN KRISIS ASIA : BEBERAPA PELAJARAN YANG DAPAT \\ DIAMBIL DARI KRISIS TERSEBUT
}

Mahdi Mahmudy *)

Krisis keuangan Asia yang pertama kali dipicu oleh devaluasi Thai Baht pada pertengahan tahun lalu telah menyeret jatuhnya nilai mata uang dan pasar modal negara-negara tetangganya seperti Malaysia, Phillipina, Korea, dan Indonesia. Semakin tenpunuknya perekonomian, mengakibatkan negara-negara yang terkena krisis untuk meminta bantuan lembaga intemasional seperti INF, world Bank dan ADB. Berbagai kebijakan ekonomi makro baik moneter, fiskal, keuangan dan sektor riil telah dicoba untuk mengatasi krisis tersebut. Namm, karena konpleks faktor penyebab, serta munulnya permasalahan sosial dan politik akibat krisis tersebut, kebijakan makro yang konvensional berupa pengetatan moneter dan fiskal belum menunjukkan hasil seperti yang diharapkan.

Krisis tersebut diperburuk oleh kondisi perekonomian Jepang yang juga sedang mengalami berbagai pemasalahan intemal. Jepang, sebagai negara yang perekonomiannya terbesar kedua didunia, merupakan lokomotif yang penting dalam mendorong perekonomian Asia dan dunia. Terpuruknya perekonomian Asia telah menbawa penganuh contagion terhadap Russia, Eropa Timur dan Amerika Iatin. Bila tidak segera diatasi secara menyeluruh dan bersama-sama, krisis tersebut diduga akan mengakibatkan krisis global dan membawa perekonomian dunia kearah depresi.

*) Mahdi Mahmudy : Peneliti Ekonomi Bagian Studi Ekonomi dan Lembaga Internasional, UREM, Bank Indonesia, Email : mahdi_m@mail.bi.go.id 
Pendahuluan

M eskipun telah memasuki usia setahun, krisis ekonomi dan keuangan Asia belum menunjukkan tanda-tanda akan berakhir. Bahkan, krisis tersebut cenderung mengglobal. Hal ini diperburuk oleh perekonomian Jepang yang juga sedang mengalami sakit yang cukup parah akibat besarnya non-performing loan sektor perbankan dan hambatanhambatan struktural lainnya. Jepang, sebagai negara yang perekonomiannya terbesar di dunia, merupakan salah satu lokomotif penting dalam mendorong perekonomian Asia dan dunia. Suramnya kondisi perekonomian Asia mempunyai pengaruh contagion terhadap kawasan lainnya.

Tulisan ini akan memaparkan mengenai hal-hal yang berkaitan dengan krisis tersebut, baik faktor-faktor penyebab, pengaruh pada perkembangan ekonomi kawasan lainnya, kebijakan yang telah diambil, serta kritikan terhadap kebijakan IMF dalam upaya-upaya penanganan krisis selama ini. Struktur organisasi penulisan akan sebagai berikut. Krisis ekonomi dan keuangan Asia serta dampaknya terhadap kawasan lainnya serta perekonomian dunia dikemukan pada bagian II. Bagian III akan menjelaskan beberapa faktor penyebab krisis muncul. Kebijakan yang diambil dalam mengatasi krisis serta kritikkritik terhadap kebijakan yang disarankan IMF dikemukan pada bagian IV. Tulisan ini akan diakhiri dengan rangkuman yang merupakan bagian $\mathrm{V}$.

Krisis Asia serta dampaknya terhadap perekonomian kawasan lainnya

Krisis Asia yang dipicu pertama kali oleh devaluasi Thai Baht pada awal Juli tahun 1997 yang lalu, kemudian dikenal dengan "Tom Yum Effect", telah membawa gelombang jatuhnya mata uang, serta melemahnya pasar modal negara-negara tetangganya seperti Malaysia, Korea, Phillipina, serta Indonesia. Bahkan negara-negara Asia yang kuat perekonomiannya seperti Singapura dan Hongkong juga tidak luput dari goncangan badai krisis tersebut. (1ihat Grafik 1 dan 2)

Lebih lanjut krisis Asia tersebut terus menggelinding dan membesar seperti bergulimya snow ball. Sakitnya perekonomian Asia telah menyebar ke Russia dan Eropa Timur. Melemahnya nilai tukar Rubel menyebabkan melemahnya mata uang serta pasar modal negara-negara yang perekonomiannya sangat terkait erat dengan Russia seperti Ukraine, Belarus, Czech Republic, Polandia, serta Rumania.

Bagaikan domino principle, epidemi krisis menelan korban berikutnya negara-negara Amerika Latin. Brazil yang perekonomiannya cukup besar dan berpengaruh terhadap perkembangan perekonomian di kawasan Amerika latin mulai terkena imbas krisis ekonomi Russia dan Asia. Ketergantungan Brazil yang sangat besar terhadap capital inflow 
Grafik 1 Perkembangan Nilai Tukar

Beberapa Mata Uang Asia Terhadap Dolar AS

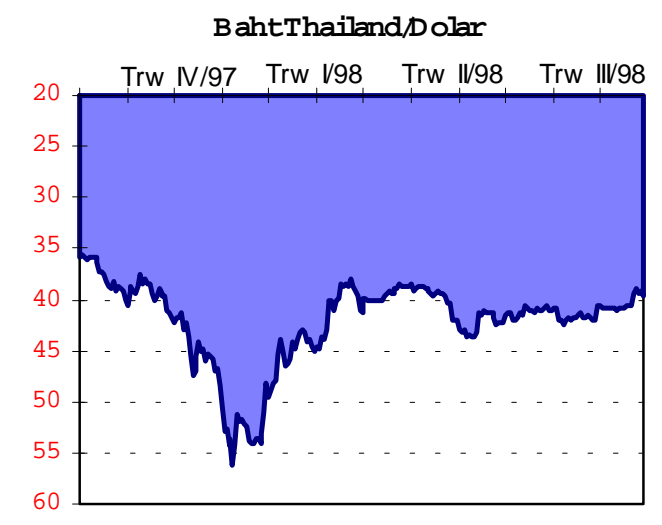

W on Korean $\$$ olar

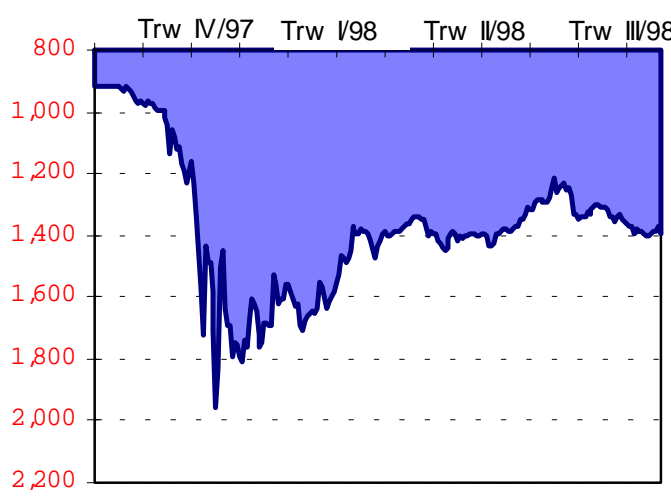

Rupiah/D olar

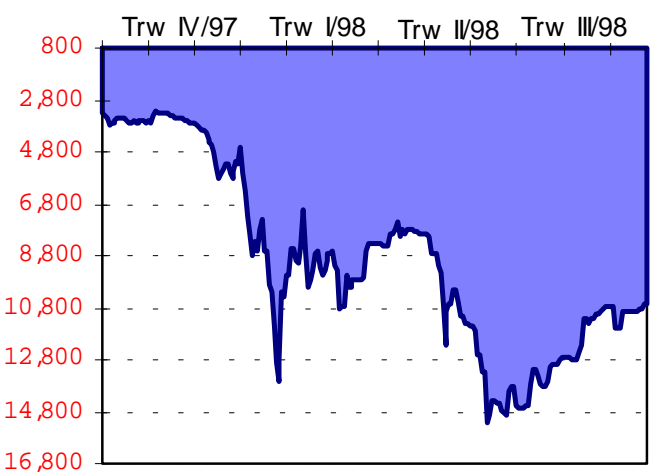

Yen Jepang D olar

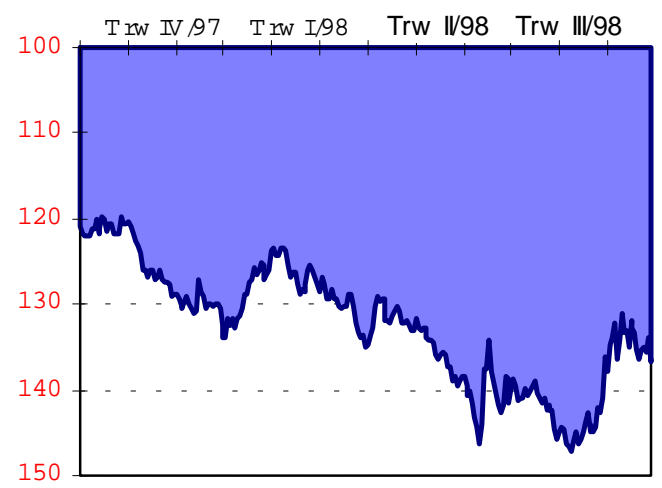

Grafik 2. Indeks Harga Saham di Beberapa Negara

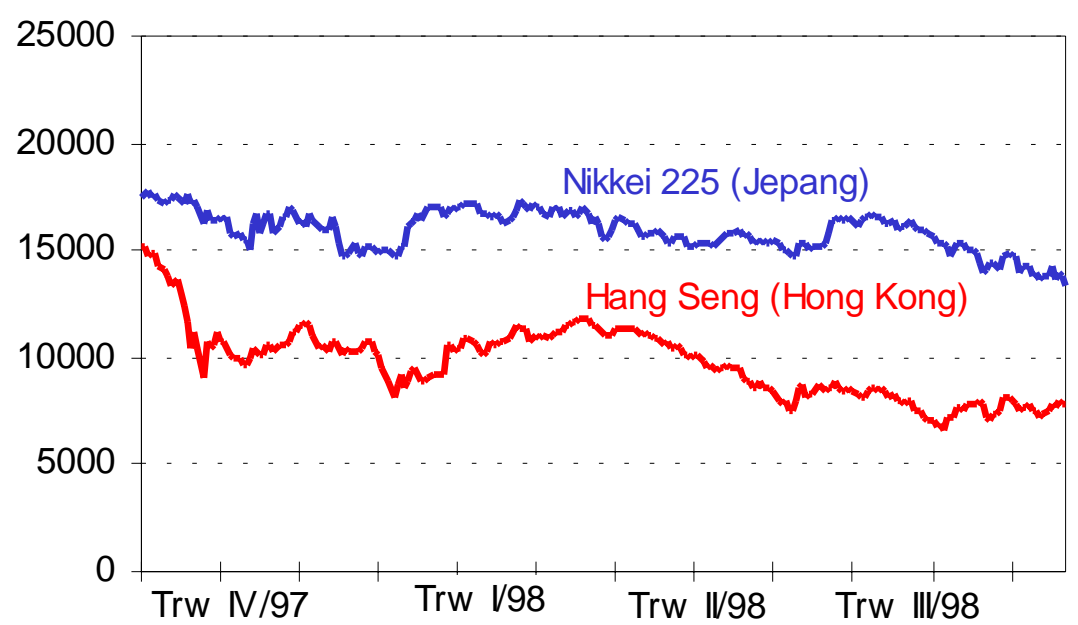


untuk membiayai anggaran defisit, sekitar 7\% dari GDP, mengakibatkan negara tersebut terpaksa membayar mahal terhadap gejala capital atflow dengan menaikkan suku bunga secara drastis mendekati 50\% pada bulan September 1998. Melemahnya perekonomian Brazil diduga akan membawa pengaruh yang buruk terhadap negara Amerika latinnya seperti Venezeula, Argentina, Columbia, Chili dan Mexico.

Krisis keuangan Asia mengakibatkan anjloknya pertumbuhan perekonomian negaranegara Asia dan Asean khususnya. Hal ini tercermin dari pertumbuhan GDP mereka. Pertumbuhan real GDP kawasan Asia dan khususnya negara-negara ASEAN-4 ${ }^{1}$ pada tahun 1997 masing masing melambat menjadi 6,6\% dan 3,7\% dari 8,2\% dan 7,1\% pada tahun sebelumnya. Dalam tahun 1997 krisis keuangan Asia secara langsung belum berdampak terhadap negara-negara industri utama. Pertumbuhan Domestik Bruto riil negara-negara industri utama tersebut secara umum (kecuali Jepang) sedikit meningkat menjadi 2,9\% dibandingkan sebesar 2,8\% pada tahun $1996^{2}$.

Namun, secara tidak langsung negara-negara industri mulai merasakan pengaruh krisis. Pengaruh tidak langsung tersebut antara lain terlihat dari jatuhnya harga-harga komoditi yang diperdagangkan. Terpuruknya perekonomian negara-negara di kawasan yang terkena krisis disertai dengan melemahnya mata uang mereka, menyebabkan jatuhnya harga tradable goods serta melambatnya perdagangan dengan negara-negara industri yang dekat dengan Asia seperti, New Zealand dan Australia. Majalah Economist ${ }^{3}$ menyebutkan dampak krisis menyebabkan commodity price index turun sebesar 30\% sejak pertengahan tahun 1997. Penurunan ini merupakan yang tertinggi sejak 25 tahun terakhir. Bahkan harga-harga industrial commodities secara riil berada pada posisi yang paling rendah sejak tahun 1930-an.

Memasuki tahun 1998, perekonomian negara-negara Asia dan Amerika Latin masih melambat. Hal ini terutama disebabkan oleh menurunnya tingkat konsumsi, investasi, serta belum pulihnya capital inflow ke kawasan tersebut ${ }^{4}$. Melambatnya pertumbuhan ekonomi negara-negara Asia dan Amerika Latin tersebut, mulai mengkhawatirkan negara-negara maju. Mereka menyadari kalau tidak segera diatasi, krisis Asia, Rusia, Eropa Timur, serta Amerika Latin bisa mengarah ke krisis global terutama karena kepanikan pelaku pasar keuangan dan menurunnya volume perdagangan dunia. Terpuruknya pasar modal dinegara-negara yang mengalami krisis mulai menunjukkan psydhology effect terhadap pasar saham Wall Street dan pasar modal negara industri lainya. Krisis Russia dan Brazil sempat

\footnotetext{
1 Indonesia, Malaysia, Phillipina, dan Thailand

2 IMF Annual Report tahun 1998

3 Edisi 5 September 1998

4 Berdasarkan World Economic and Finanacial Surveys 1998(IMF), krisis Asia mengakibatkan total net private capital inflows tahun 1997 ke Asia anjlok menjadi US\$13,9 miliar dari US\$110,4 miliar tahun 1996.
} 


\section{Grafik 3. Indeks Harga Saham di Negara Maju}

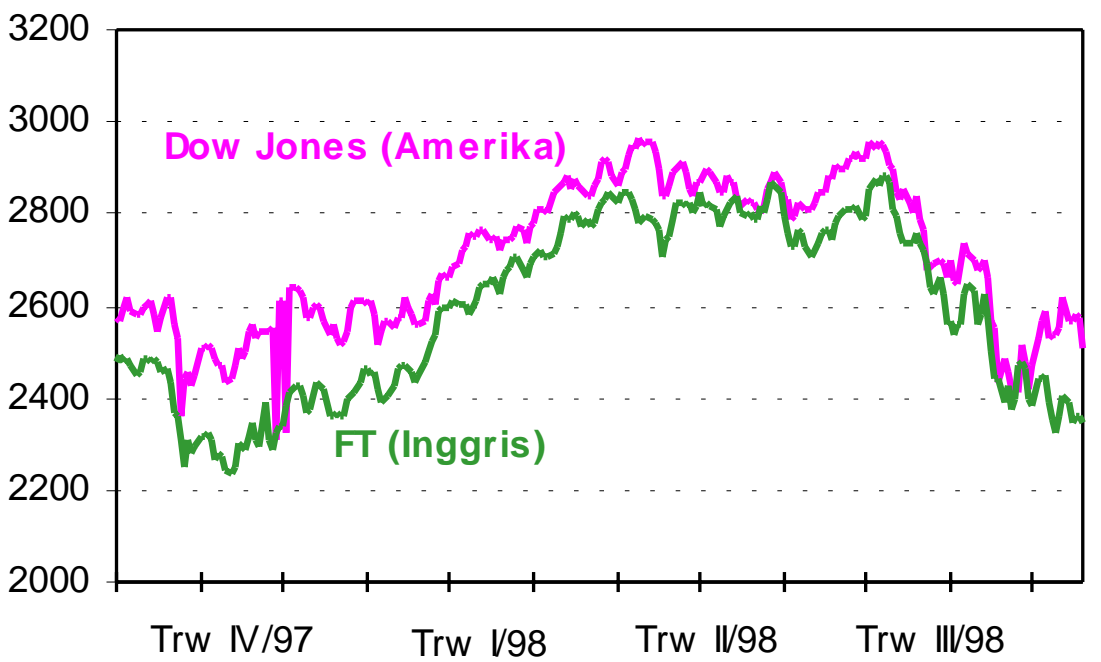

membuat panik pelaku pasar atau investor Amerika, sehingga mereka mulai menjual saham yang mereka miliki. (lihat Grafik 3) .

Dengan perkembangan-perkembangan tersebut, IMF memperkirakan pertumbuhan world ouput dalam tahun 1998 hanya 2,0\%, menurun dibandingkan dengan pertumbuhan tahun 1997 sebesar 4,1\%. Amerika pada mulanya menganggap dan yakin krisis Asia tidak akan mempunyai dampak terhadap perekonomian mereka. Namun, setelah melihat Rusia, Eropa Timur dan Amerika Latin juga terkena, serta perekonomian Jepang yang masih terpuruk, mulai khawatir terhadap perekonomian mereka. Hal ini terlihat dari proyeksi pertumbuhan ekonomi Amerika pada tahun 1998 menjadi 3,5\% dibandingkan pertumbuhan tahun sebelumnya 3,9\%.

Faktor-faktor penyebab krisis

Secara garis besar ada beberapa faktor pemicu krisis keuangan dan ekonomi tersebut. Pertama, karena besarnya hutang perusahaan swasta seperti Indonesia, Korea, dan Thailand. Disamping besar jumlahnya, pada negara-negara tertentu (Thailand, Korea dan Indonesia) hutang swasta tersebut cenderung tidak di hedge, berjangka pendek, serta digunakan untuk pembiayaan investasi di real estate serta non-tradable goods lainnya. Kedua, free capital mobility terutama yang berjangka pendek. Dengan adanya globalisasi dan semakin terintegrasinya pasar keuangan dunia, perubahan persepsi pasar atau adanya upaya spekulasi hedge fund akan mengakibatkan berbaliknya arus aliran modal secara massive yang lebih lanjut akan 
menekan nilai tukar dan mempengaruhi inflasi ${ }^{5}$. Ketiga, karena lemahnya sektor keuangan. Liberalisasi sektor keuangan mengakibatkan cepatnya pertumbuhan sistem keuangan. Pertumbuhan yang cepat tersebut cenderung tidak diikuti dengan rambu-rambu pengaman serta sistem pengawasan yang handal. Besarnya pinjaman luar negeri dari sektor keuangan yang tampa di hedge dan berjangka pendek banyak dijumpai pada negara-negara Asia. Financial panic merupakan faktor keempat penyebab krisis. Situasi bank nun karena masyarakat panik terhadap anjloknya nilai tukar serta adanya beberapa bank yang collapse dan ditutup, mengakibatkan masyarakat menarik dananya dari sistem perbankan untuk di simpan di rumah, dibelikan hard arrencies, atau ditransfer ke luar negeri. Kondisi krisis ini pada negara tertentu, seperti Indonesia, mengakibatkan pergantian pemerintahan yang diikuti oleh munculnya masalah-masalah non-ekonomi seperti social unrest, serta tekanan-tekanan politik terhadap pemerintah. Keadaan ini telah membuat kegiatan pemulihan ekonomi menjadi semakin lama.

Kebijakan yang diambil serta beberapa kritik terhadap kebijakan IMF

Melemahnya mata uang negara-negara Asia disertai dengan menurunnya cadangan devisa, baik dalam rangka intervensi untuk memperkuat nilai tukar, maupun karena adanya capital ouflow, membuat negara yang terkena krisis tersebut meminta bantuan lembaga intemasional seperti $\mathbb{I M F}$, World Bank, ADB, serta pinjaman bilateral lainnya. Resep kebijakan yang disepakati IMF untuk mengatasi pemasalahan krisis tersebut, meliputi berbagai langkah kebijakan ekonomi makro baik dibidang moneter dan fiskal, keuangan, serta sektor riil.

Dibidang moneter, dilakukan upaya-upaya pengetatan antara lain dengan menaikkan suku bunga dan pengetatan kredit. Tujuan dari kebijakan tersebut antara lain untuk memperkuat nilai tukar dan mengatasi inflasi yang tinggi. Disamping itu, kebijakan moneter yang ketat juga diharapkan akan mengembalikan kepercayaan pasar. Dalam hal kebijakan nilai tukar, dianjurkan untuk menerapkan nilai tukar yang fleksibel. Thailand dan Phillipines sejak krisis mengambangkan nilai tukar mereka, sementara Indonesia menghapuskan intervention band dan membiarkan rupiah mengambang sejak tanggal 14 Agustus 1998 untuk mengurangi upaya spekulasi dan mempertahankan cadangan devisa.

Dibidang fiskal, pada tahap awal IMF menekankan perlunya pelaksanaan kebijakan fiskal yang ketat untuk membantu kontraksi moneter dan memperkuat nilai tukar. Namun, kemudian IMF merubah stance kebijakan fiskal dari ketat menjadi longgar, karena keadaan yang tidak memungkinkan. Sebagai contoh, IMF menyetujui perubahan kebijakan fiskal yang semula ketat menjadi sedikit longgar pada Indonesia. Hal ini dikarenakan Indonesia negara

5 Berdasarkan "World Economic and Finacial Surveys 1998" (IMF), krisis Asia mengakibatkan total net private capital inflows tahun 1997 ke Indonesia, Malaysia, Philipina, dan Thailand menjadi negatif US\$ 11 miliar dari US\$ 72,9 miliar tahun 1996 
yang paling parah terkena krisis keuangan di Asia. Krisis di Indonesia mengakibatkan tingginya tingkat pengangguran, meningkatnya jumlah orang yang berada dibawah garis kemiskinan yang berdasarkan perkiran Bank dunia sekitar 45 juta atau 21\% dari total penduduk. Disamping itu, dalam tahun 1998 perekonomian Indonesia diperkirakan mengalami pertumbuhan negatif $13 \%-15 \%$. Untuk mengurangi dampak negatif dan munculnya social unrest dari krisis tersebut, program jaringan pengaman sosial ( social safety nets) dan pemberian subsidi untuk beberapa komoditas disepakati untuk dilaksanakan. Untuk TA 1998/99 fiskal defisit Indonesia diperkirakan 8,5\% dari GDP yang selunuhnya akan dibiayai dari luar negeri.

Disektor perbankan, IMF menyarankan untuk meningkatkan pengawasan, serta melakukan restrukturisasi perbankan antara lain dengan melakukan penutupan bank-bank yang tidak sehat seperti penutupan 16 bank di Indonesia, 58 finance companies di Thailand, serta 14 merchant banks di Korea. Disamping itu, perbankan nasional juga diminta untuk meningkatkan kemampuan mereka dengan mengacu kepada standard perbankan internasional seperti mengenai perluasan cakupan asset-asset procuktif, penyediaan loan loss provision (penyisihan penghapusan aktiva produktif), serta ketentuan Capital Adequacy Ratio.

Disamping itu, dalam upaya mengurangi tekanan permintaan terhadap USD yang lebih lanjut bisa memperlemah nilai tukar, kebijakan untuk menjadwalkan kembali hutang swasta dan pemerintah juga dilaksanakan oleh Korea dan Indonesia. Sebagai contoh, Indonesia berhasil melakukan rescheduling hutang swasta melalui berbagai pertemuan yaitu di New York pada bulan April 1998, Tokyo pada bulan Mei 1998, serta disepakatinya Frankfurt Agreement, pada bulan Juni 1998, antara swasta dan lender luar negeri. Kemudian dilanjuti dengan Paris Club Meeting untuk menjadwalkan kembali hutang-hutang Pemerintah yang jatuh tempo pada TA 1998/99 - sekitar US\$ 1,8 miliar.

Di sektor rill dilakukan berbagai kebijakan deregulasi dan restrukturisasi dalam rangka meningkatkan efisiensi perekonomian nasional. Berbagai hambatan perdagangan termasuk monopoli dan oligopoli dalam kegiatan ekonomi dihapuskan. Demikian pula hambatan-hambatan terhadap kegiatan investasi asing dikurangi. Berbagai subsidi secara bertahap akan di hapus. Reformasi struktural dilakukan diberbagai bidang, misalnya, pada perdagangan dalam dan luar negeri. Disamping itu, Korea dan Indonesia berupaya untuk mempercepat privatisasi perusahaan-perusahaan Pemerintah.

Kritikan-kritikan terhadap kebijakan IMF dalam mengatasi krisis

Penanganan krisis oleh IMF melalui kebijakan pengetatan atau demand restraint mendapat kritik banyak pakar ekonomi seperti Jeffrey Sachs (The Head of Harvard Institute for International Development) dan Paul Krugman. 
Sach, misalnya, mengkritik kebijakan IMF mengenai penutupan bank di beberapa negara. Penutupan bank-bank yang tidak sehat di Thailand dan Indonesia dalam kondisi normal mungkin akan membawa dampak positif. Namun, dalam kondisi keuangan yang tidak normal, dan belum adanya skim deposit insurance, penutupan bank bank tersebut semakin memacu kepanikan dan ketidak percayaan masyarakat terhadap sistem keuangan. Hal ini mengakibatkan masyarakat menarik dananya secara besar-besaran dari perbankan. Di Indonesia, kondisi bank nu ini lebih lanjut mengakibatkan fligtt to safety yaitu perpindahan dana dari bank-bank swasta ke bank pemerintah dan bank asing. Selanjutnya hal ini mengakibatkan liquidity squeeze yang mengakibatkan perbankan sulit untuk melakukan penghimpunan maupun penyaluran dana. Perkembangan tersebut mengakibatkan kreditor luar negeri juga enggan untuk memperpanjang kembali hutang mereka ke perbankan yang mengakibatkan semakin ketatnya likuiditas dan tingginya suku bunga.

Sachs juga mengkritik saran IMF yang menganjurkan negara-negara Asia yang mengalami krisis untuk mentargetkan surplus budget sebesar 1\% dari GDP. Hal ini karena negara-negara tersebut selama ini umumnya telah melaksanakan kebijakan fiskal yang berhati-hati dan inti pemasalahan krisis bukan bersumber dari fiskal. Pengetatan fiskal dalam kondisi perekonomian yang sudah kontraksi akan mengakibatkan perekonomian semakin dalam terpuruk. IMF kelihatannya menyadari kondisi ini, dan akhirnya mengizinkan negara-negara yang terkena krisis untuk melaksanakan deficit ludget.

Mengenai kebijakan moneter yang ketat dalam hal ekspansi kredit dan peningkatan suku bunga untuk mengurangi likuiditas perekonomian guna memperkuat nilai tukar, menurut Sach tidak banyak bermanfaat dalam kondisi financial panic. Tingginya suku bunga dan ketatnya penyaluran kredit mengakibatkan bank mengalami negatif spread, nonperfoming loan meningkat, serta cenderung merugi. Ketatnya pemberian kredit, diikuti dengan tingginya suku bunga mengakibatkan pasar modal dan sektor real semakin terpuruk, serta meningkatkan unemployment. (lihat Grafik 4a dan 4b).

Paul Krugman ${ }^{6}$, menulis dalam berbagai artikel di majalah Fortune dan Far Eastern Economic Review, yakin bahwa upaya temporary arrency control disertai dengan penurunan suku bunga atau dikenal dengan "Plan B" merupakan bagian upaya yang penting untuk mengatasi krisis Asia. Hal ini berhubung kebijakan-kebijakan IMF (Plan A) dalam mengatasi krisis Asia selama ini tidak hanya gagal tetapi telah mempenburuk situasi.

Lebih jauh Krugman menyatakan bahwa dalam menerapkan kebijakan kontrol devisa tersebut, suatu negara harus selalu mengacu pada upaya menekan hambatan-hambatan pelaksanaan kegiatan usaha seminimal mungkin. Pertama, pelaksanaan kontrol sebagus

6 Professor of economics at the Massachusetts Institute of Technology 
Grafik 4a. Indeks Harga Saham di Beberapa Negara

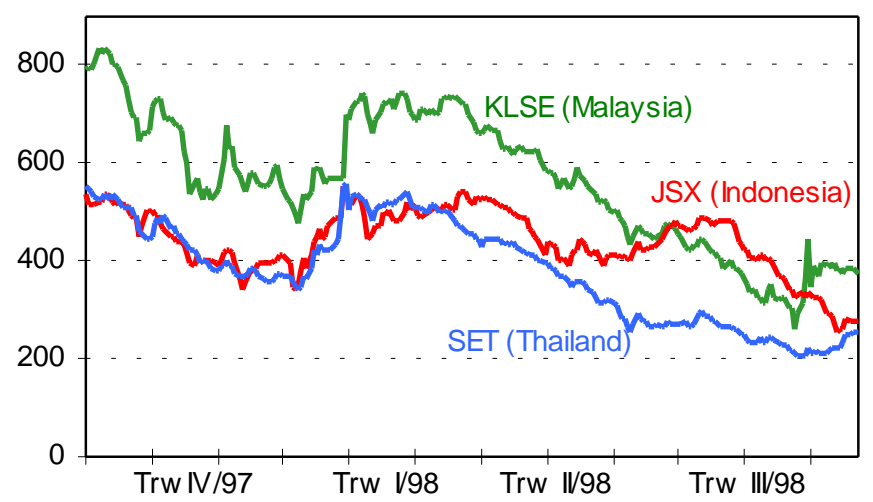

apapun akan menimbulkan distorsi yang dapat memperparah kondisi perekonomian. Sehubungan dengan itu, kebijakan pengendalian nilai tukar ini hendaknya bersifat sementara untuk memberikan ruang gerak bagi pemulihan ekonomi. Kedua, kontrol devisa dan pemberlakuan nilai tukar tetap hendaknya ditujukan untuk mempertahankan nilai tukar yang tinggi semata karena yang diperlukan adalah nilai tukar real yang kompetitif untuk menunjang ekspor. Ketiga, kebijakan pengendalian nilai tukar hendaknya digunakan sebagai alat bantu reformasi ekonomi sehingga memberikan ruang gerak bagi pelaksanaan kebijakan moneter dan fiskal yang ekspansif untuk memacu kegiatan sektor real. Namun, upaya lainnya menyangkut pembenahan sektor keuangan tetap harus dipercepat.

Negara Asia yang menerapkan ide Krugman tersebut adalah Malaysia dengan memberlakukan selective exchange control (ECM) pada tanggal 1 september 1998 yang baru

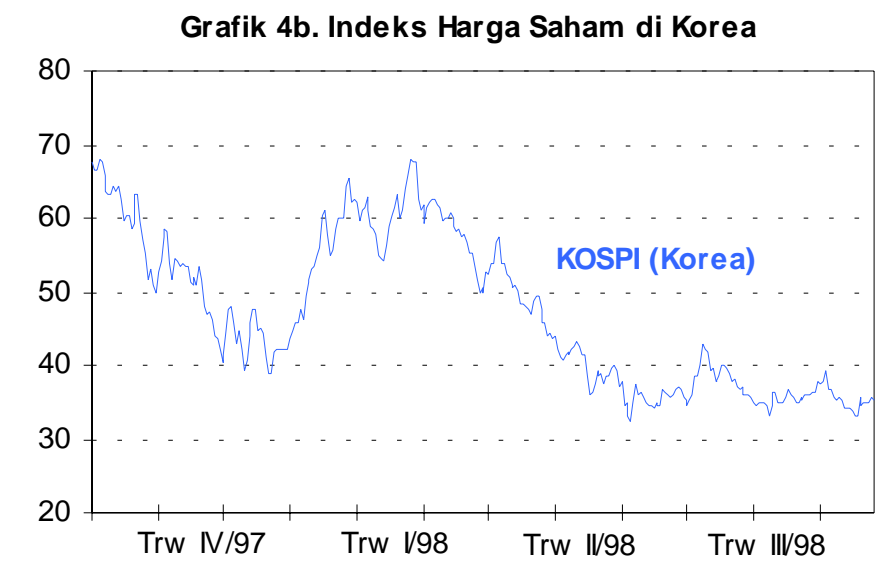

7 Bank Negara Malaysia,'”'Measures to Regain Monetary Independence”, press release, September 1998 
lalu. Kebijakan ini diambil untuk mengendalikan nilai tukar Malaysian Ringgit (RM) yang melemah, menghambat spekulasi terhadap RM, dan meminimumkan dampak negatif dari arus modal jangka pendek terhadap perekonomian domestik. Kebijakan ECM tersebut diikuti dengan kebijakan kurs tetap dan pelonggaran kebijakan moneter dengan penurunan suku bunga untuk mendorong kegiatan sektor real. Kebijakan ECM yang drastis ini diambil Malaysia karena menilai kebijakan moneter yang ketat dan restrukturisasi keuangan yang dilakukan selama ini tidak menolong banyak dalam mengatasi krisis selama ini, bahkan telah memperburuk kondisi yang ada.

Negara Asia lain yang cukup berhati-hati dan bertahap dalam meliberalisasi transaksi devisa adalah RRC. Sampai saat ini RRC masih membatasi eksportir dalam kepemilikan devisa yaitu sekitar 15\% dari hasil penerimaan ekspor. Mata uang Ren Min Bi (RMB) diupayakan tidak menjadi convertible arrency . Namun, untuk investasi jangka panjang, negara tersebut relatif terbuka terutama untuk sektor high-tech industry dan prasarana ${ }^{8}$.

Kritik yang keras terhadap IMF juga dilontarkan oleh PM Inggris, Tony Blair. Dalam debat tahunan di Majelis umum PBB pada tanggal 21 september yang baru lalu ia mengatakan bahwa IMF dan World Bank sebagai lembaga yang dibentuk untuk mengelola perekonomian cunia tidak bisa lagi dipertahankan karena adanya gejolak pasar uang global. Untuk itu perlu new Bretton Wood System untuk menghadapi millenium yang akan datang.

\section{Penutup}

- Dengan adanya globalisasi disektor keuangan, pengaruh contagion terhadap negara lain menjadi semakin besar. Oleh karena itu setiap negara harus mempunyai sistem keuangan yang handal, kebijakan ekonomi makro yang solid dan berhati-hati, serta kestabilan politik, guna mengurangi dampak negatif globalisasi.

- Perlu ditingkatkan kerja sama ekonomi intra kawasan yang lebih erat dalam rangka meningkatkan pertumbuhan ekonomi, dan mempertahankan stabilitas mata uang di kawasan. Disamping itu, perlu dipercepat upaya pembentukan pengawasan regional (ASEAN Monitoring Mechanism) yang merupakan early warning system untuk mengetahui permasalahan di masing-masing negara dan kawasan guna mencari kebijakan yang tepat untuk mengatasinya. ASEAN Monitoring Mechanism ini diharapkan dapat melengkapi bentuk pengawasan yang dilakukan oleh IMF selama ini.

8 Berdasarkan data the 1998 APEC Economic Outlook, Foreign Direct investment ke China pada tahun 1997 mencapai US $\$ 45,3$ miliar. 
- Guna mengantisipasi permasalahan ekonomi pada abad 21 mendatang, dan menghindari seringnya terjadi fluktuasi nilai tukar mata uang negara-negara anggota di kawasan ASEAN, perlu dirintis upaya untuk menciptakan satu mata uang tunggal di Asia atau khususnya ASEAN seperti mata tunggal uang Eropa (EMU). EMU yang akan diberlakukan pada Januari 1999 yang akan datang, persiapan pembentukannya dilakukan lebih dari 20 tahun.

- Krisis Asia yang telah menyebar ke Russia dan Eropa Timur, serta Amerika latin, bila tidak diatasi secara menyeluruh dan sungguh-sungguh oleh lembaga-lembaga internasional dan negara G7 bisa mengakibatkan krisis global dan membawa perekonomian ke arah depresi.

- Free capital mobility khususnya yang berjangka pendek perlu dilakukan pengaturannya secara internasional, sebab arus modal tersebut yang dari tahun ketahun semakin besar volumenya disertai dengan transaksi derivative yang cukup kompleks mempunyai andil yang besar dalam menciptakan krisis terutama pada emerging markets .

- Lembaga internasional perlu menyusun suatu early waming system terhadap kondisi ekonomi makro negara-negara anggota untuk menghindari krisis perekonomian yang lebih luas. Disamping itu perlu ditingkatkan transpararancy, akurasi serta timely data ekonomi makro dan keuangan setiap negara.

- Berdasarkan pengalaman negara yang menganut sistem keuangannya yang lebih tertutup disertai adanya rambu-rambu dalam pnudential regulation atas arus modal jangka pendek, seperti China, kelihatannya tidak mudah terkena imbas krisis ekonomi yang terjadi.

- Last lat not least cukup menarik pendapat Stiglitz" (World Bank) mengenai negara yang menganut sistem ekonomi terbuka dalam kaitannya dengan capital flows "Small open economies are like rowing boats on an open sea. One can not predict when they might capsize; bad steering increases the chances of disaster and a leaky boat makes it inevitable. But their chances of being broadsided by a wave are significant no matter how well they are steered and no matter how seaworthy they are. The financial movements of the past few years are like the sea ".

\section{Daftar Pustaka}

APEC Economic Outlook , August 1998.

ASEAN Central Bank Forum, Meeting of Deputies, Kuala Lumpur, September 6, 1998.

9 Joseph Stiglitz dalam artikel Boats, planes and capital flows 
Bank Indonesia, UREM -Bagian SEI, Catatan Perihal Kebijakan Pengendalian Nilai Tukar Malaysia, September 1998.

Bank Negara Malaysia, Measures to Regain Monetary Independence, press release, September 1998

Camdessus, Michael, From the Asian Crisis Toward a New global Architecture.

Economist, edisi 5 September 1998.

Graciela L. Kaminsky and Carmen M. Reinhart, Financial Crises in Asia and Latin America : Then and Now, January 1998.

International Monetary Fund, Annual Report 1998 .

International Monetary Fund, World Economic Outlook, September 1998.

Krugman, Paul, Far Eastern Economic review dan Fortune,

Report of the Subcomitte on Asian Financial and Capital Market of the Committee on Foreign Exchange and Other Transaction, Lessons from the Asian Currency Crises.

Reuters

Sach, Jeffrey, IMF is a power unto itself, December 1997.

Steven Radelet and Jeffrey Sachs, The Onset of the Asian Financial Crisis, February 1998.

Stiglitz, Joseph, Boat Planes, and Capital Flows, March 1998. 
Lampiran

Tabel 1

Pertumbuhan Ekonomi Negara Maju dan Negara Berkembang ${ }^{\text {*) }}$

dalam persen

\begin{tabular}{|c|c|c|c|c|c|c|c|}
\hline & \multirow[b]{2}{*}{1993} & \multirow[b]{2}{*}{1994} & \multirow[b]{2}{*}{1995} & \multirow[b]{2}{*}{1996} & \multirow[b]{2}{*}{1997} & \multicolumn{2}{|c|}{ Proyeksi } \\
\hline & & & & & & 1998 & 1999 \\
\hline Dunia & 2.6 & 3.9 & 3.6 & 4,2 & 4.1 & 2.0 & 2.5 \\
\hline Negara-negara maju & 1.2 & 3.2 & 2.5 & 3.0 & 3.1 & 2.0 & 1.9 \\
\hline Negara-negara industri utama & 1.0 & 2.8 & 2.0 & 2.8 & 2.9 & 2.1 & 1.9 \\
\hline Amerika Serikat & 2.3 & 3.5 & 2.0 & 3.4 & 3.9 & 3.5 & 2.0 \\
\hline Inggeris & 2.1 & 4.3 & 2.7 & 2.2 & 3.4 & 2.3 & 1.2 \\
\hline Italia & -1.2 & 2.2 & 2.9 & 0.7 & 1.5 & 2.1 & 2.5 \\
\hline Jepang & 0.3 & 0.6 & 1.5 & 3.9 & 0.8 & -2.5 & 0.5 \\
\hline Jerman & -1.2 & 2.7 & 1.8 & 1.3 & 2.2 & 2.6 & 2.5 \\
\hline Kanada & 2.2 & 4.1 & 2.3 & 1.2 & 3.7 & 3.0 & 2.5 \\
\hline New Zealand & 5.1 & 6.0 & 3.9 & 3.1 & 2.3 & -0.5 & 1.7 \\
\hline Negara-negara berkembang & 6.5 & 6.8 & 5.9 & 6.6 & 5.8 & 2.3 & 3.6 \\
\hline Berdasarkan kawasan & & & & & & & \\
\hline Afrika & 1.0 & 2.6 & 2.9 & 5.8 & 3.2 & 3.7 & 4.7 \\
\hline Asia & 9.3 & 9.6 & 8.9 & 8.2 & 6.6 & 1.8 & 3.9 \\
\hline ASEAN-4 & n.a. & n.a. & n.a. & 7.1 & 3.7 & -10.4 & -0.1 \\
\hline China & 13.5 & 12.6 & 10.5 & 9.6 & 8.8 & 5.5 & n.a \\
\hline Eropa dan Timur Tengah & 3.9 & 0.7 & 3.5 & 4.7 & 4.5 & 3.2 & 3.9 \\
\hline Amerika Latin & 3.6 & 5.0 & 1.2 & 3.5 & 5.1 & 2.8 & 2.7 \\
\hline Argentina & 6.3 & 8.5 & -4.6 & 4.8 & 8.6 & 5.0 & n.a \\
\hline Brazilia & 4.9 & 5.9 & 4.2 & 2.8 & 3.2 & 1.5 & n.a \\
\hline Chile & 7.0 & 5.7 & 10.6 & 7.4 & 7.1 & 4.5 & n.a \\
\hline Columbia & 5.4 & 5.8 & 5.8 & 2.1 & 3.1 & 2.7 & n.a \\
\hline Negara industri baru Asia (NIEs) & 6.3 & 7.6 & 7.3 & 6.3 & 6.1 & -1.6 & 1.7 \\
\hline Hong Kong SAR & 6.1 & 5.4 & 3.9 & 4.6 & 5.3 & -5.0 & 0.0 \\
\hline Korea & 5.8 & 8.6 & 8.9 & 7.1 & 5.5 & -7.0 & -1.0 \\
\hline Singapura & 10.4 & 10.5 & 8.8 & 6.9 & 7.8 & 0.0 & 0.2 \\
\hline Taiwan & 6.3 & 6.5 & 6.0 & 5.7 & 6.9 & 4.0 & 3.9 \\
\hline Negara-negara AS EAN & & & & & & & \\
\hline Brunei Darussalam & 0.5 & 1.8 & 2.0 & 2.8 & 3.5 & n.a. & n.a. \\
\hline Indonesia & 6.5 & 7.5 & 8.2 & 8.0 & 4.6 & -13.8 & -2.3 \\
\hline Philipina & 2.1 & 4.4 & 4.8 & 5.7 & 5.1 & -0.6 & n.a \\
\hline Malay sia & 8.3 & 9.2 & 9.5 & 8.6 & 7.8 & -6.4 & n.a \\
\hline Thailand & 8.5 & 8.9 & 8.7 & 5.5 & -0.4 & -8.0 & n.a \\
\hline Negara-negara dalam transisi & -6.7 & -7.6 & -1.3 & -0.1 & 2.0 & 1.8 & 3.0 \\
\hline Eropa Tengah dan Timur & -4.1 & -2.6 & 1.3 & 1.6 & 2.8 & 3.5 & 4.1 \\
\hline di luar Belarus dan Ukraina & -0.2 & 3.5 & 5.1 & 3.7 & 3.2 & 3.9 & 4.4 \\
\hline Rusia & -8.7 & -12.6 & -4.0 & -5.0 & 0.9 & -6.0 & 1.0 \\
\hline
\end{tabular}

*) Produk Domestik Bruto riil.

Sumber : $\quad$ - IMF, World Economic Outlook, August 1998

- IMF, International Financial Statistics, September 1998

- Bank Indonesia, Laporan Tahunan (untuk data Indonesia) 
Tabel 2

Laju Inflasi Negara Maju dan Negara Berkembang

\begin{tabular}{|c|c|c|c|c|c|c|}
\hline & \multirow[b]{2}{*}{1994} & \multirow[b]{2}{*}{1995} & \multirow[b]{2}{*}{1996} & \multirow[b]{2}{*}{1997} & \multicolumn{2}{|c|}{ Proyeksi } \\
\hline & & & & & 1998 & 1999 \\
\hline Negara-negara maju & 2.6 & 2.5 & 2.4 & 2.1 & 1.7 & 1.7 \\
\hline Negara-negara industri utama & 2.2 & 2.3 & 2.2 & 2.0 & 1.4 & 1.6 \\
\hline Amerika Serikat & 2.6 & 2.8 & 2.9 & 2.3 & 1.6 & 2.3 \\
\hline Inggeris $\left.{ }^{*}\right)$ & 2.4 & 2.8 & 2.9 & 2.8 & 2.8 & 2.8 \\
\hline Italia & 4.1 & 5.2 & 3.9 & 1.7 & 1.8 & 1.7 \\
\hline Jepang & 0.7 & -0.1 & 0.1 & 1.7 & 0.4 & -0.5 \\
\hline Jerman & 2.7 & 1.8 & 1.5 & 1.8 & 1.0 & 1.4 \\
\hline Kanada & 0.2 & 2.2 & 1.6 & 1.4 & 1.3 & 1.9 \\
\hline New Zealand & & & 2.3 & 1.7 & 1.4 & 1.6 \\
\hline Negara-negara berkembang & 51.0 & 22.7 & 13.4 & 8.5 & 10.5 & 7.7 \\
\hline \multicolumn{7}{|l|}{ Berdasarkan kawasan } \\
\hline Afrika & 39.3 & 32.9 & 26.7 & 11.0 & 7.7 & 7.0 \\
\hline Asia & 14.8 & 11.9 & 7.9 & 4.7 & 8.3 & 6.7 \\
\hline Eropa dan Timur Tengah & 31.9 & 35.7 & 24.6 & 22.6 & 22.6 & 13.7 \\
\hline Amerika Latin & 208.5 & 41.6 & 20.8 & 13.9 & 10.8 & 8.0 \\
\hline Argentina & 4.2 & 3.4 & 0.2 & 0.8 & 1.3 & n.a \\
\hline Brazilia & 2123.7 & 59.6 & 11.1 & 7.9 & 5.0 & n.a \\
\hline Chile & 11.4 & 8.2 & 7.4 & 6.1 & 5.4 & n.a \\
\hline Columbia & 22.8 & 20.9 & 20.8 & 18.5 & 19.5 & n.a \\
\hline Negara indus tri baru Asia (NIEs) & 5.6 & 4.6 & 4.2 & 3.2 & 5.6 & 3.2 \\
\hline Hong Kong SAR & 9.5 & 7.1 & 6.0 & 5.7 & 3.0 & -3.8 \\
\hline Korea & 6.2 & 4.5 & 4.9 & 4.4 & 8.5 & 4.3 \\
\hline Singapura & 3.0 & 1.8 & 1.4 & 2.0 & 1.8 & 2.0 \\
\hline Taiwan & 2.6 & 4.6 & 3.1 & 2.1 & 2.0 & 2.0 \\
\hline \multicolumn{7}{|l|}{ Negara-negara ASEAN } \\
\hline Brunei Darussalam & 2.4 & 6.0 & 2.0 & 3.0 & n.a. & n.a. \\
\hline Indonesia & 9.2 & 8.6 & 6.6 & 10.3 & 89.4 & 39.6 \\
\hline Philipina & 9.0 & 8.1 & 8.4 & 6.0 & 10.0 & n.a. \\
\hline Malaysia & 3.7 & 3.4 & 3.5 & 2.7 & 6.0 & n.a. \\
\hline Thailand & 5.1 & 5.8 & 5.9 & 5.6 & 9.0 & n.a. \\
\hline Negara-negara dalam transisi & 268.4 & 128.6 & 41.0 & 28.0 & 30.0 & n.a. \\
\hline Eropa Tengah dan Timur & 153.3 & 75.3 & 32.0 & 38.0 & 18.0 & n.a. \\
\hline Di luar Belarus dan Ukraina & 45.1 & 25.1 & 23.0 & 41.0 & 17.0 & n.a. \\
\hline Rusia & 302.0 & 190.1 & 48.0 & 15.0 & 48.0 & n.a. \\
\hline
\end{tabular}

*) Indeks harga eceran di luar bunga hipotik.

Sumber: - IMF, World Economic Outlook, August 1998.

- Bank Indonesia, Laporan Tahunan (untuk data Indonesia)

- J.P. Morgan. Emerging Markets: Economics Indicators, Juli 1998 
Tabel 3

Perkembangan Harga Beberapa Komoditas Primer Nonminyak

\begin{tabular}{|l|c|c|c|c|c|}
\hline Jenis Komoditas & $\mathbf{1 9 9 4}$ & $\mathbf{1 9 9 5}$ & $\mathbf{1 9 9 6}$ & $\mathbf{1 9 9 7}$ & $\mathbf{1 9 9 8}^{*}$ \\
\hline $\begin{array}{l}\text { Kopi (sen \$/pound) } \\
\text { Dari Brasil (di New York) }\end{array}$ & 143.32 & 145.98 & 120.29 & 166.8 & 96.23 \\
$\begin{array}{l}\text { Emas (\$/fine ounce) } \\
\text { Inggeris }\end{array}$ & 384.22 & 384.16 & 387.82 & 331.1 & 292.75 \\
$\begin{array}{l}\text { Nikel (sen \$/pound) } \\
\text { Inggeris }\end{array}$ & 287.21 & 373.02 & 340.38 & 314.1 & 196.52 \\
$\begin{array}{l}\text { Karet (sen \$/pound) } \\
\text { Semua jenis (di New York) } \\
\text { Timah (sen \$/pound) } \\
\text { London }\end{array}$ & 48.93 & 56.65 & 54.83 & 53.54 & 52.63 \\
$\begin{array}{l}\text { Tembaga (sen \$/pound) } \\
\text { Inggeris }\end{array}$ & 104.58 & 133 & 104.03 & 103.2 & 75.1 \\
\hline
\end{tabular}

*) Sampai dengan Juli 1998.

Sumber: IMF, International Financial Statistics, September 1998 
Tabel 4

Private Capital Flows ke Emerging Market

\begin{tabular}{|c|c|c|c|c|c|c|c|c|}
\hline & 1990 & 1991 & 1992 & 1993 & 1994 & 1995 & 1996 & 1997 \\
\hline \multicolumn{9}{|l|}{ Emerging Market } \\
\hline Total Net Private Capital Inflows ${ }^{1)}$ & 31 & 126.9 & 120.9 & 164.7 & 160.5 & 192 & 240.8 & 173.7 \\
\hline Net Foreign Direct Investment & 17.6 & 31.3 & 37.2 & 60.6 & 84.3 & 96 & 114.9 & 138.2 \\
\hline Net Portfolio Investment & 17.1 & 37.3 & 59.9 & 103.5 & 87.8 & 23.5 & 49.7 & 42.9 \\
\hline Others & -3.7 & 58.4 & 23.8 & 0.7 & -11.7 & 72.5 & 76.2 & -7.3 \\
\hline \multicolumn{9}{|l|}{ Asia } \\
\hline Total Net Private Capital Inflows & 19.1 & 35.8 & 21.7 & 57.6 & 66.2 & 95.8 & 110.4 & 13.9 \\
\hline Net Foreign Direct Investment & 8.9 & 14.5 & 16.5 & 35.9 & 46.8 & 49.5 & 57 & 57.8 \\
\hline Net Portfolio Investment & -1.4 & 1.8 & 9.3 & 21.6 & 9.5 & 10.5 & 13.4 & -8.6 \\
\hline Others & 11.6 & 19.5 & -4.1 & 0.1 & 9.9 & 35.8 & 39.9 & -35.4 \\
\hline \multicolumn{9}{|l|}{ Amerika Latin } \\
\hline Total Net Private Capital Inflows & 10.1 & 26.1 & 56 & 64.3 & 47.4 & 35.7 & 80.5 & 91.1 \\
\hline Net Foreign Direct Investment & 6.7 & 11 & 13.6 & 12.8 & 24.3 & 25.3 & 36.9 & 51.2 \\
\hline Net Portfolio Investment & 17.5 & 14.7 & 30.4 & 61.1 & 60.6 & -0.1 & 25.2 & 33.5 \\
\hline Others & -14 & 0.3 & 12 & -9.5 & -37.5 & 10.5 & 18.5 & 6.5 \\
\hline \multicolumn{9}{|l|}{ Negara Asia yang mengalami krisis ${ }^{2)}$} \\
\hline Total Net Private Capital Inflows & 24.9 & 29 & 30.3 & 32.6 & 35.1 & 62.9 & 72.9 & -11 \\
\hline Net Foreign Direct Investment & 6.2 & 7.2 & 8.6 & 8.6 & 7.4 & 9.5 & 12 & 9.6 \\
\hline Net Portfolio Investment & 1.3 & 3.3 & 6.3 & 17.9 & 10.6 & 14.4 & 20.3 & 11.8 \\
\hline Others & 17.4 & 18.5 & 15.4 & 6.1 & 17.1 & 39 & 40.6 & -32.3 \\
\hline \multicolumn{9}{|l|}{ Timur Tengah dan Eropa } \\
\hline Total Net Private Capital Inflows & 0.2 & 65.7 & 38 & 26.6 & 17.9 & 16.9 & 24.4 & 25.4 \\
\hline Net Foreign Direct Investment & 1 & 1.3 & 1 & 3.9 & 4.3 & 3.7 & 2.6 & 3.3 \\
\hline Net Portfolio Investment & 2.6 & 22.3 & 20.9 & 15.4 & 13.2 & 8.8 & 9.2 & 8.2 \\
\hline Others & -3.4 & 42.2 & 16.1 & 7.3 & 0.5 & 4.4 & 12.4 & 13.9 \\
\hline \multicolumn{9}{|l|}{ Negara-negara dalam transisi } \\
\hline Total Net Private Capital Inflows & 3.5 & -2.4 & 7.2 & 12.2 & 18.4 & 29.8 & 21.3 & 34.5 \\
\hline Net Foreign Direct Investment & -0.3 & 2.4 & 4.2 & 6 & 5.4 & 13.2 & 13.1 & 18.2 \\
\hline Net Portfolio Investment & 0 & 0 & 0.1 & 4.5 & 4.1 & 2.9 & 2.2 & 7.3 \\
\hline Others & 3.7 & -4.8 & 2.9 & 1.7 & 8.9 & 13.6 & 5.9 & 9 \\
\hline
\end{tabular}

Sumber : International Monetary Fund, International Financial Statistics and World Economic Outlook database.

1) Net Foreign Direct Investment ditambah Net Portfolio Investment dan Net Other Investment

2) Indonesia, Korea, Malaysia, Philipines, Thailand 
Tabel 5

Harga dan Volume Perdagangan Dunia

\begin{tabular}{|c|c|c|c|c|c|c|}
\hline & \multirow[b]{2}{*}{1994} & \multirow[b]{2}{*}{1995} & \multirow[b]{2}{*}{1996} & \multirow[b]{2}{*}{1997} & \multicolumn{2}{|c|}{ Proyeksi } \\
\hline & & & & & 1998 & 1999 \\
\hline \multicolumn{7}{|l|}{ Perdagangan barang dan jasa } \\
\hline $\begin{array}{l}\text { Volume } \\
\text { Deflator harga }\end{array}$ & 9.3 & 9.5 & 6.7 & 9.8 & 4.6 & 5.6 \\
\hline Dalam dolar AS & 2.3 & 8.3 & -1.1 & -5.8 & -4.1 & 1.3 \\
\hline Dalam SDR & -0.2 & 2.2 & 3.3 & -0.6 & -0.6 & 1.8 \\
\hline $\begin{array}{l}\text { Volume perdagangan } \\
\text { Ekspor }\end{array}$ & & & & & & \\
\hline Negara-negara maju & 8.8 & 8.8 & 5.9 & 10.1 & 4.1 & 5.2 \\
\hline $\begin{array}{l}\text { Negara-negara berkembang } \\
\text { Impor }\end{array}$ & 13.0 & 10.5 & 8.8 & 10.6 & 4.8 & 6.1 \\
\hline Negara-negara maju & 9.7 & 8.9 & 6.4 & 8.8 & 5.2 & 5.3 \\
\hline $\begin{array}{l}\text { Negara-negara berkembang } \\
\text { Nilai tukar dagang }\end{array}$ & 7.0 & 11.9 & 8.2 & 12.4 & 3.6 & 6.5 \\
\hline Negara-negara maju & 0.0 & 0.1 & 0.0 & -0.7 & 0.5 & -0.3 \\
\hline $\begin{array}{l}\text { Negara-negara berkembang } \\
\text { Perdagangan barang }\end{array}$ & -0.2 & 1.8 & 1.9 & 0.6 & -2.3 & 1.0 \\
\hline Perdagangan dunia & & & & & & \\
\hline $\begin{array}{l}\text { Volume } \\
\text { Deflator harga }\end{array}$ & 10.2 & 10.2 & 6.5 & 10.3 & 4.8 & 5.6 \\
\hline Dalam dolar AS & 2.5 & 8.5 & -1.2 & -6.2 & -4.5 & 1.4 \\
\hline $\begin{array}{l}\text { Dalam SDR } \\
\text { Harga dalam dolar AS }\end{array}$ & 0.0 & 2.4 & 3.2 & -1.0 & -2.3 & 1.9 \\
\hline M anufaktur & 3.1 & 10.3 & -3.2 & -9.4 & -3.2 & 0.7 \\
\hline M iny ak & -5.5 & 8.0 & 18.4 & -5.4 & -28.0 & 13.0 \\
\hline $\begin{array}{l}\text { Komoditas primer nonmigas } \\
\text { Harga dalam dolar SDR }\end{array}$ & 13.6 & 8.2 & -1.2 & -3.3 & -13.4 & 0.9 \\
\hline $\begin{array}{l}\text { Manufaktur } \\
\text { Minyak }\end{array}$ & $\begin{array}{c}0.5 \\
-7.8\end{array}$ & $\begin{array}{l}4.1 \\
1.9\end{array}$ & $\begin{array}{c}1.2 \\
23.7\end{array}$ & $\begin{array}{l}-4.4 \\
-0.2\end{array}$ & $\begin{array}{l}-1.0 \\
-26.4\end{array}$ & $\begin{array}{c}1.2 \\
13.6\end{array}$ \\
\hline Komoditas primer nonmigas & 10.8 & 2.1 & 3.3 & 2.0 & -11.5 & 1.3 \\
\hline $\begin{array}{l}\text { Volume perdagangan } \\
\text { Ekspor }\end{array}$ & & & & & & \\
\hline Negara-negara maju & 9.4 & 9.4 & 5.9 & 10.7 & 4.4 & 5.1 \\
\hline $\begin{array}{l}\text { Negara-negara berkembang } \\
\text { Pengekspor migas }\end{array}$ & $\begin{array}{c}14.3 \\
8.1\end{array}$ & $\begin{array}{c}11.9 \\
2.6\end{array}$ & $\begin{array}{l}8.3 \\
6.3\end{array}$ & $\begin{array}{c}11.2 \\
6.9\end{array}$ & $\begin{array}{l}4.9 \\
1.2\end{array}$ & $\begin{array}{l}6.3 \\
5.0\end{array}$ \\
\hline $\begin{array}{l}\text { Pengekspor migas } \\
\text { Bukan pengekspor migas }\end{array}$ & 16.5 & 14.7 & 8.9 & $\begin{array}{l}0.9 \\
12.4\end{array}$ & 6.0 & 6.6 \\
\hline Impor & & & & & & \\
\hline Negara-negara maju & 11.0 & 9.4 & 5.7 & 9.7 & 5.6 & 5.4 \\
\hline Negara-negara berkem bang & 7.6 & 12.6 & 9.1 & 10.5 & 3.0 & 6.8 \\
\hline Pengekspor migas & -11.1 & 4.5 & 1.1 & 15.5 & 3.7 & 6.5 \\
\hline Buk an pengekspor migas & 11.9 & 14.1 & 10.5 & 9.7 & 2.8 & 6.9 \\
\hline $\begin{array}{l}\text { Deflator harga dalam SDR } \\
\text { Ekspor }\end{array}$ & & & & & & \\
\hline Negara-negara maju & 0.4 & 3.0 & 1.7 & -2.4 & -2.4 & 1.4 \\
\hline Negara-negara berkembang & -0.8 & 1.1 & 8.0 & 3.0 & -4.0 & 3.0 \\
\hline Pengekspor migas & -7.9 & 2.1 & 15.8 & 2.8 & -13.9 & 7.7 \\
\hline Buk an pengekspor migas & 1.7 & 0.8 & 5.8 & 3.1 & -1.2 & 1.9 \\
\hline Impor & & & & & & \\
\hline Negara-negara maju & -0.2 & 2.8 & 2.6 & -1.6 & -2.8 & 2.2 \\
\hline Negara-negara berkembang & -0.3 & -1.1 & 5.0 & 2.5 & -0.6 & 1.9 \\
\hline Pengekspor migas & -1.1 & 0.6 & 4.0 & 2.6 & 1.3 & 1.5 \\
\hline Bukan pengekspor migas & -0.1 & -1.4 & 5.2 & 2.5 & -1.0 & 1.9 \\
\hline Nilai tukar dagang & & & & & & \\
\hline Negara-negara maju & 0.5 & 0.2 & -1.0 & -0.8 & 0.4 & -0.7 \\
\hline Negara-negara berkem bang & -0.5 & 2.2 & 2.8 & 0.5 & -3.4 & 1.1 \\
\hline Pengekspor migas & -6.8 & 1.4 & 11.3 & 0.2 & -15.1 & 6.1 \\
\hline Bukan pengekspor migas & 1.9 & 2.2 & 0.6 & 0.6 & -0.3 & -0.1 \\
\hline
\end{tabular}

Sumber : IMF, World Econom ic Outlook, August 1998 